\title{
A Glossary of \\ Italian Political Parties
}

DC Democrazia Cristiana

MSI Movimento Sociale Italiano

PCI Partito Comunista Italiano

PLI Partito Liberale Italiano

PNM Partito Nazionale Monarchico

PRI Partito Repubblicano Italiano

PSDI Partito Socialista Democratico Italiano

PSI Partito Socialista Italiano

PSIUP Partito Socialista Italiano di Unità Proletaria 